\title{
Neurological evaluation after radical resection of sacral neoplasms
}

\author{
Y Fujimura MD, H Maruiwa MD, T Takahata MD, Y Toyama MD \\ Department of Orthopaedic Surgery, School of Medicine, Keio University, \\ 35 Shinanomachi, Shinjuku-ku, Tokyo, 160 Japan.
}

\begin{abstract}
Eight patients had a radical resection of sacral tumours, and bilateral severance of lumbosacral nerves was required. Their neurological deficits and disturbance of activities of daily living (ADL) were studied. The neurological deficits which occurred were motor dysfunction of the lower limbs, sensory disturbances, and urinary, faecal and sexual dysfunction. Bilateral preservation of the L5 nerve and above was necessary to permit the ability to walk, and bilateral preservation of the S2 nerve and above was necessary to spare urinary, faecal and sexual functions in order to establish ADL. To maintain normal ADL, bilateral preservation of the S2 nerve and above was necessary for walking, and bilateral preservation of the S3 nerve and above was necessary for urinary, faecal and sexual functions.
\end{abstract}
Keywords: sacral tumours; radical resection, severance of lumbosacral nerves; neurological deficit; activities of daily living.

\section{Introduction}

Radical resection is employed for the radical treatment of giant sacral tumours and tumours of relatively low malignancy possessing a high possibility of local recurrence. ${ }^{1-12}$ Radical sacral tumour resection is a surgical procedure presenting several .problems because it is not only technically difficult but may also be associated with such sequelae as neurological dysfunction and instability of the pelvic girdle resulting from sacral amputation. . $7,13-16$ Nowadays, radical sacral tumour resection and reconstruction of the sacrum is possible as a result of advancements in radiological imaging diagnosis and in surgical techniques. . $^{5,11,16-19}$ including embolisation to help to control intraoperative haemorrhage, and because of the development of instrumentation to obtain secure spinal fixation. ${ }^{12,20-22}$ Thus radical resection̆ should be performed 'aggressively' to treat such sacral tumours although some neurological function must be sacrificed. Reconstruction of the sacrum with instrumentation was performed when it was felt that there would be postoperative instability of the pelvic girdle. However, the degree of neurological dys- function such as disturbance of motor function of the lower limbs, of urinary, bowel and sexual function depended on the level and extent of spinal nerve severance. The degree of neurological dysfunction may become absolutely unacceptable in regard to the patients' postoperative ADL. The objectives of this study were to investigate the resulting neurological deficits relative to the level of spinal nerve severance, and to clarify these with ADL disturbance after bilateral severance of lumbosacral nerves.

\section{Methods}

The subjects of this study were eight patients who underwent radical sacral tumour resection with bilateral severance of the lumbosacral nerves during the 12 year period from 1981 to 1992 . There were six males and two females, and their ages at the time of surgery were from 17 to 74 years with an average of 56 years. The pathological diagnosis in three cases was a chordoma and there were single examples of Ewing's sarcoma, chondrosarcoma, giant cell tumour, meningioma and ependymoma. Radical resection was performed on three 
patients, including those with the giant cell tumour, meningioma and ependymoma because of recurrence after a previous operation. Radical sacral tumour resection was performed in all of the cases with the addition of reconstruction of the sacrum in six cases. Autologous bone, hydroxyapatite or bone cement was used for reconstruction of the sacrum, and fixation instrumentation was employed in three cases (Figs 1-3). The levels of lumbosacral nerve severance were L4-S5 on the right side and L5-S5 on the left in one case, bilaterally L5-S5 in one case, bilaterally S1-S5 in two cases, bilaterally $\mathrm{S} 2-\mathrm{S} 5$ in one case, bilaterally $\mathrm{S} 3-\mathrm{S} 5$ in two cases, and S3-S5 on the right side and S4 and S5 on the left in one case. The follow up period ranged from 9 to 98 months with an average of 36 months (Table I). No signs of local recurrence were present at the final follow up. Neurological deficit was carefully evaluated. ADL disturbance was also evaluated. Although the presence of preoperative neurological deficit and the possibility of the effect-of surgical manoeuvers may not be excluded, neurological deficit was considered to be related to the innervation of nerves in which neurological function was preserved.

\section{Results}

Motor function of the lower limbs

In the patient whose L4 nerve and below on the right side and L5 nerve and below on the left were severed (case 1), the quadriceps muscles were bilaterally grade 4 ; however, the right tibialis anterior muscle was grade 0 and the left was grade 2 , and the extensor hallucis longus, gastrocnemius and flexor hallucis longus muscles were grade 0 . The patient was able to stand up with support but could not walk. In case 2, where the L5 nerve and below were severed bilaterally, the right tibialis anterior muscle was grade 4 and the left was grade 3, the extensor hallucis longus and gastrocnemius muscles were grade 3 , and the flexor hallucis longus muscles were grade 0 . Application of a short leg brace on one side and the use of T-canes on both sides allowed this patient to walk. In the patients whose S1 nerve and below a

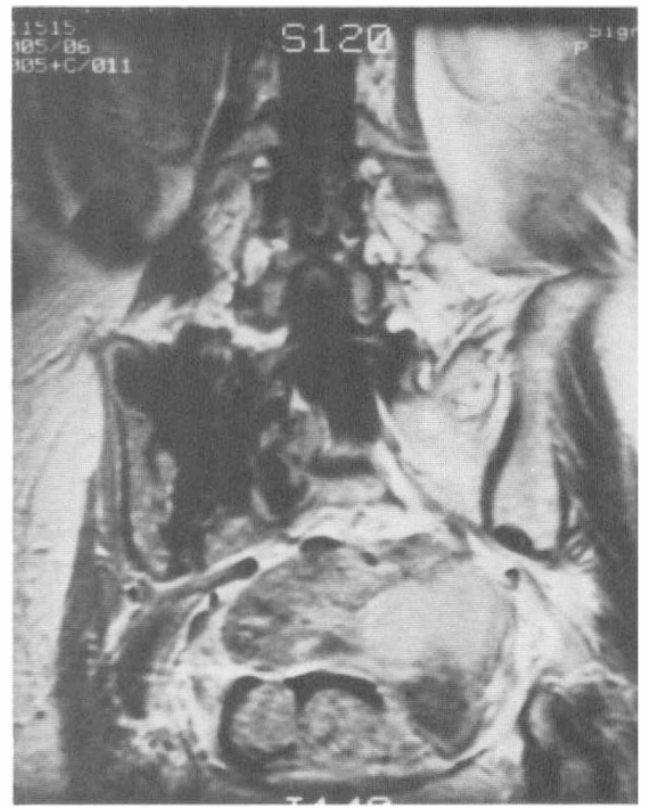

b

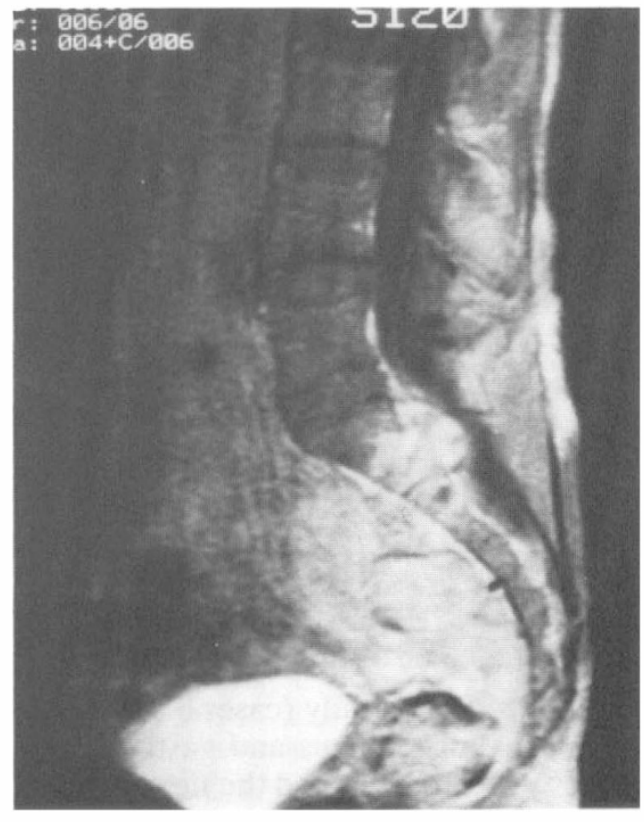

Figure 1 (a) and (b). Caption on p. 398. 


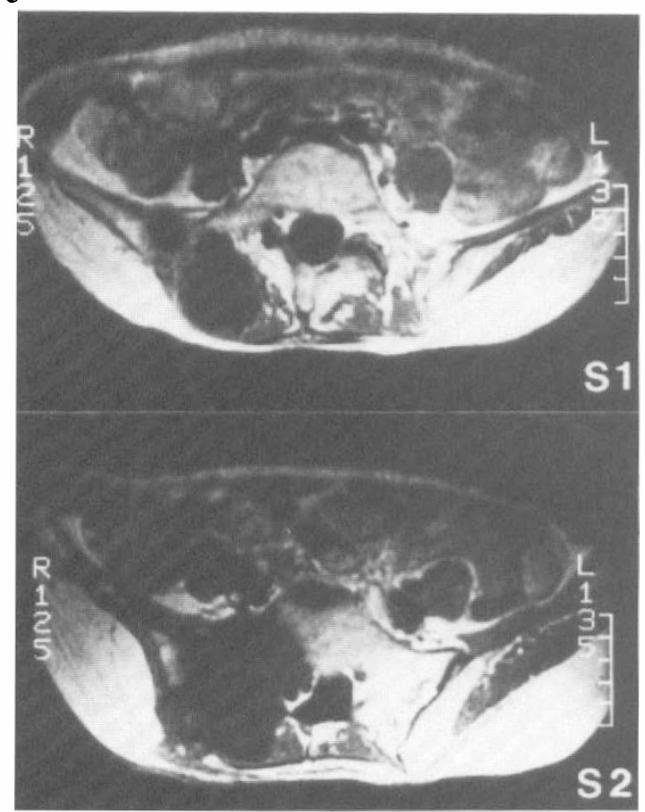

d

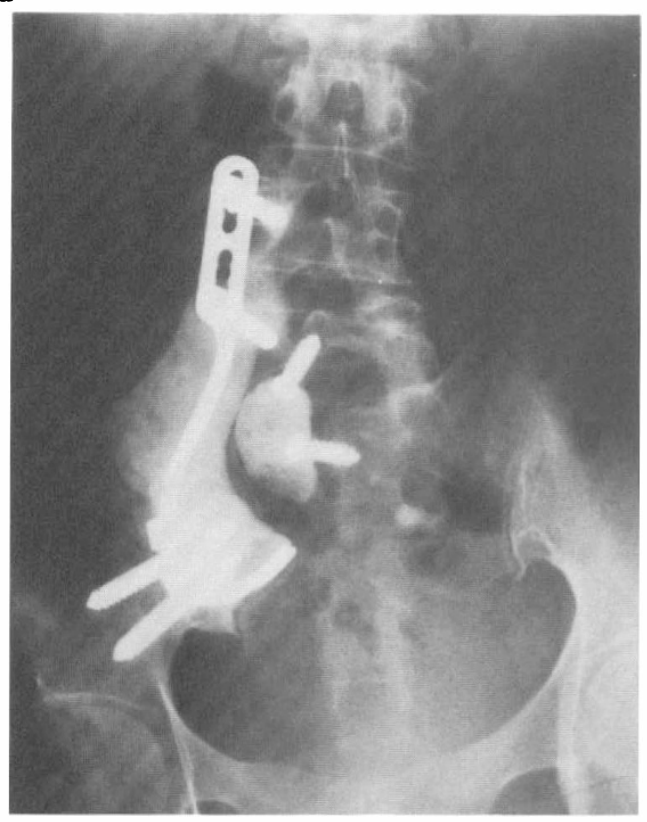

were severed bilaterally (cases 3 and 4), the extensor hallucis longus and gastrocnemius muscles were grade 4 , and the flexor hallucis longus muscles were grade 3 . These patients required to use handrails when descending

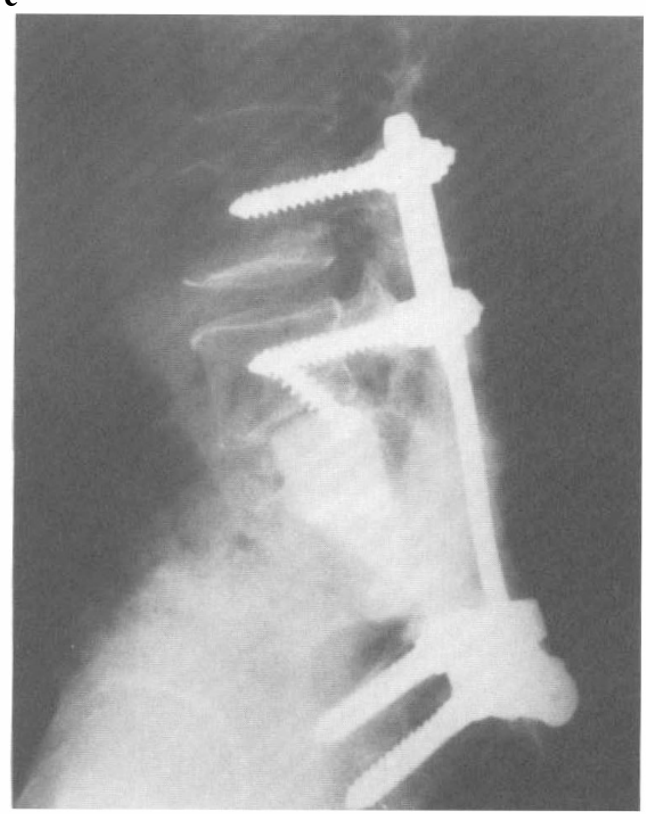

Figure 1 Case 1. 58 year old female with chondrosarcoma of the sacroiliac bone on the right side. (a) Preoperative Gd-DTPA enhanced T1-weighted coronal MRI. (b) Preoperative Gd-DTPA enhanced T1-weighted sagittal MRI. (c) Preoperative T1-weighted axial MRI at the level of S1 and S2. (d, e) The sacroiliac reconstruction with ISOLA and bone cement was performed following radical tumour resection.

stairs, but were able to walk on flat surfaces. In the patient whose S2 nerve and below were severed bilaterally (case 5), a slight decrease in muscle strength was present in both legs before surgery. Muscle strength 


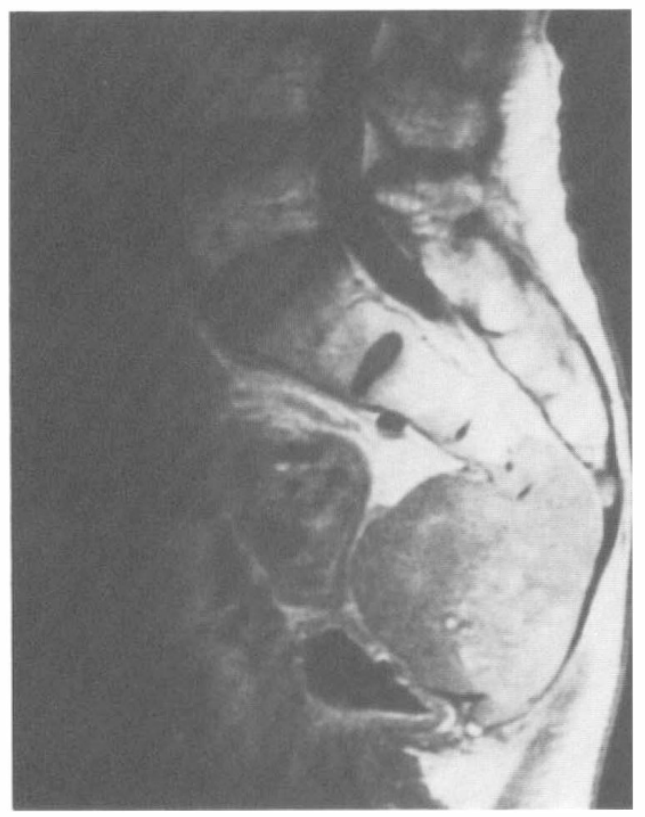

b

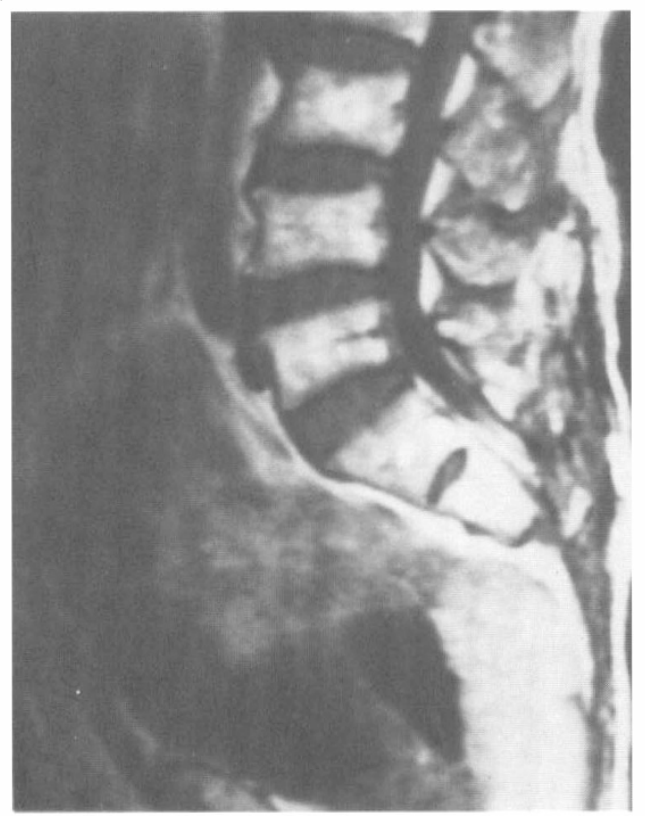

Figure 2 Case 7. 71 year old male with chordoma of the sacrum. (a) Preoperative GdDTPA enhanced T1-weighted sagittal MRI showed a large presacral tumour mass. (b) T1-weighted sagittal MRI showed no evidence of local tumour recurrence at 27 months after radical tumour resection. did not change and the patient was able to walk after the operation. In the patients whose S3 nerve and below were severed bilaterally (cases 6 and 7) and whose S3 nerve and below on the right side and S4 nerve and below on the left were severed (case 8), a decrease in muscle strength of the lower limbs did not occur and walking was normal (Table II).

\section{Reflexes}

The right patellar reflex was lost and the left was decreased in case 1 , but that reflex was present in all of the cases whose L4 nerves were preserved bilaterally (cases $2-8$ ). The ankle jerk was absent after bilateral severance of the S1 nerves (cases 1-4), but was present when the $\mathrm{S} 1$ nerves were preserved bilaterally (cases 5-8). The anal reflex was spared in case 8 but was lost in the other cases in which the S3 nerve and above were severed bilaterally (Table II).

\section{Sensation}

Hypaesthesia and anaesthesia occurred at spinal levels below the nerve severance level. Sensory disturbance occurred from one spinal segment above the level of nerve severance in three cases (cases 2, 4 and 5). Sensation of the penis or labia were spared, and, although analgesia occurred, touch sensation in the perianal region was slightly preserved after severance of the S3 nerve and below (cases 6-8) (Table II).

\section{Urinary function}

Urinary dysfunction occurred in all of the patients. Case 8 had normal sensation, but this was replaced by a sense of fullness of the lower abdomen in patients whose S3 nerve and above were severed. Residual urine was present in all of the patients, but only a small amount was found in case 8 . All patients had urinary incontinence with the exception of case 8 . In cases 6 and 7, urinary incontinence was minimal. Micturition was almost normal in case 8 . The other patients were able to micturate by manual abdominal pressure. An indwelling catheter was 
a

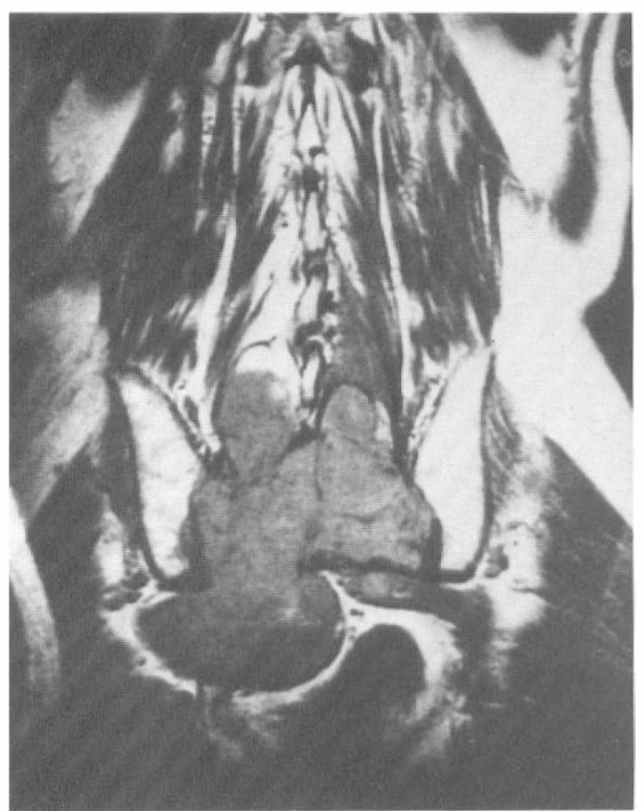

b

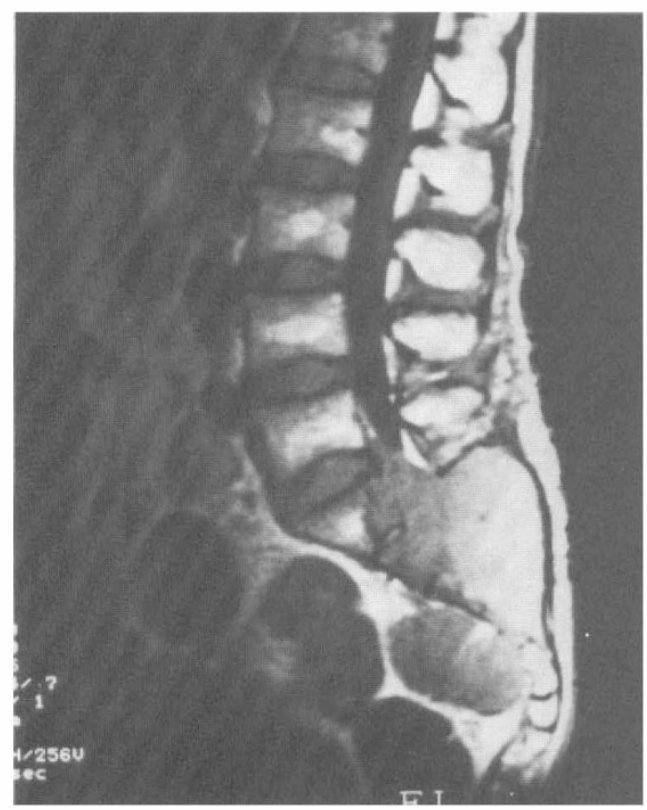

c

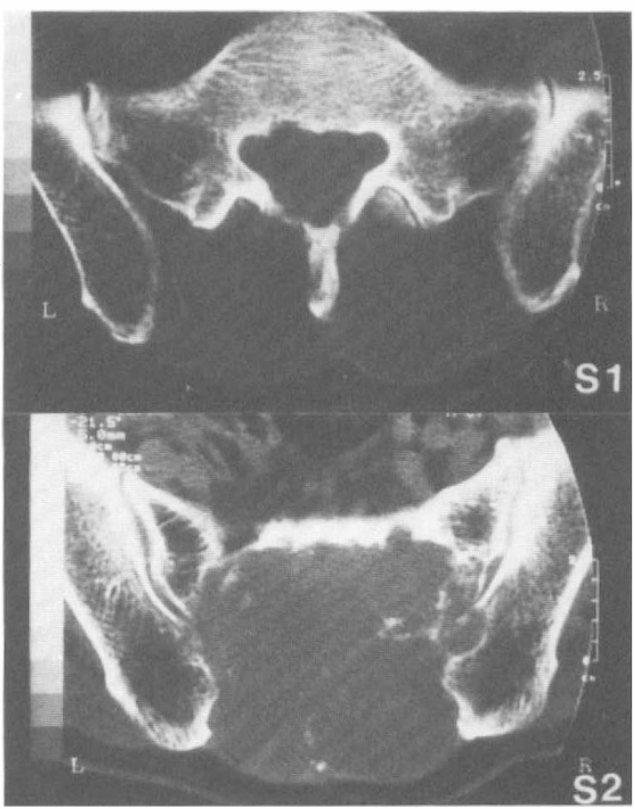

d

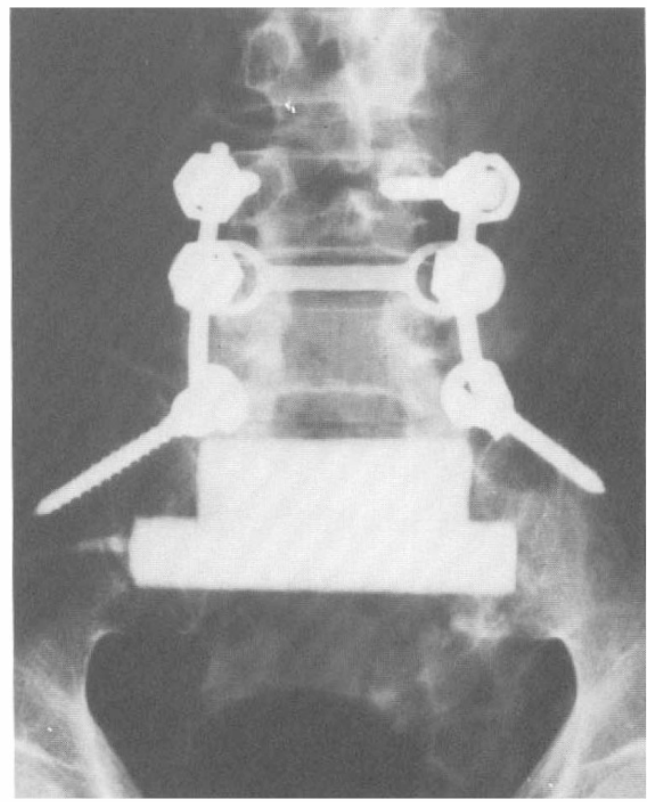

Figure 3 (a)-(d). Caption on p. 401. 
$\mathbf{e}$

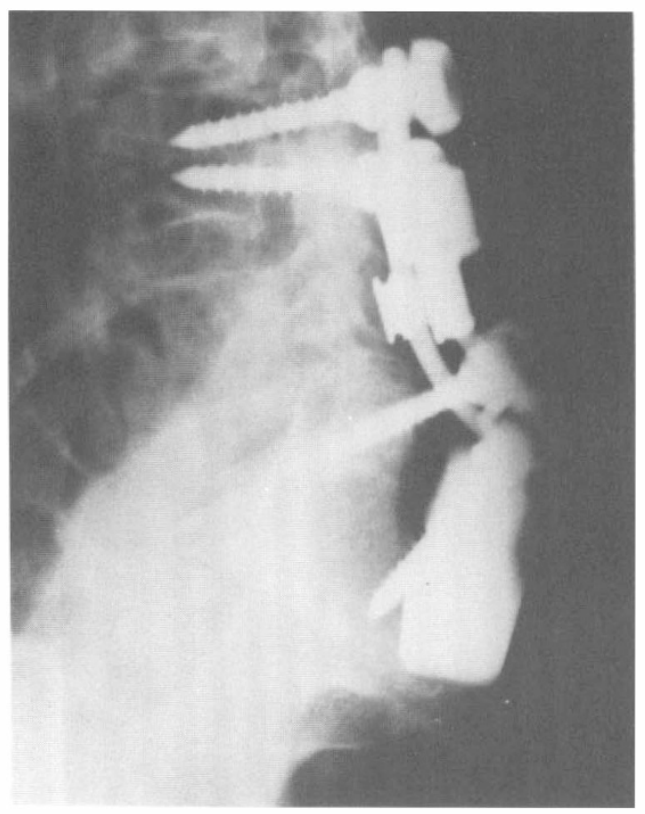

Figure 3 Case 8.74 year old male with chordoma of the sacrum. (a) Preoperative T1weighted coronal MRI. (b) Preoperative T1weighted sagittal MRI. (c) Preoperative CT at the level of S1 and S2. (d, e) The reconstruction of the sacrum with Spine system ${ }^{\circledR}$ and hydroxyapatite was performed following radical tumour resection.

unnecessary, but medication and intermittent self catheterisation were necessary (Table III).

\section{Bowel function}

With the exception of case 8 , bowel dysfunction occurred in all of the patients. The normal defaecation desire was replaced by a sense of fullness or uneasiness in the lower abdomen. Constipation also occurred. In patients whose S2 nerve and below were severed (cases 1-5), anal sphincter tone was lost and diapers became necessary because of faecal incontinence. However, the patients were able to defaecate with manual assistance and abdominal pressure when the faeces was solid. After bilateral severance of the S3 nerve and below (cases 6 and 7), the tone of the external anal sphincter remained and defaecation of solid faeces was possible, but clothing was soiled by soft faeces because of faecal incontinence (Table III).

\section{Sexual function}

This was studied in the male patients. Erection and ejaculation were lost after bilateral severance of the S1 nerve and above. A weak erection occurred but ejaculation was not possible after bilateral severance of the S2 nerve and below (case 5). After bilateral severance of the S3 nerve and below (cases 6 and 7), dripping of semen occurred instead of normal ejaculation. In case 8 whose S3 nerves were preserved bilaterally, erection and ejaculation were maintained at close to preoperative levels (Table III).

\section{Discussion}

Surgical treatment is indicated for primary vertebral and spinal tumours of the sacrum that are benign or are of relatively low malignancy and possess a strong possibility of local recurrence, such as giant cell tumour, chordoma, chondrosarcoma, meningioma, and ependymoma, because conservative therapy is ineffective. ${ }^{1-12}$ Patients with sacral tumours often die because of distal metastases.,6,11 Therefore, radical sacral tumour resection is the surgical procedure of choice, but severance of some sacral nerves cannot be avoided when radical sacral tumour resection is performed. High sacral amputation is, as is also total resection of the sacrum, associated with instability of the pelvic girdle and with neurological dysfunction. ${ }^{7,13-16}$ The advancement in instrumentation has allowed reconstruction of the sacrum if instability of the pelvic girdle is likely to occur postoperatively. At present, postoperative neurological dysfunction is the greatest problem because it is a permanent complication.

The major types of postoperative neurological dysfunction associated with radical sacrum tumour resection are motor disturbance of the lower limbs and urinary, faecal and sexual dyfunction. There are only a few reports on the relationship between neurological dysfunction and ADL. 1,3,12 Gunterberg et al gave a detailed report on a 
Table I Surgical cases of radical resection for sacral tumours

\begin{tabular}{|c|c|c|c|c|c|c|}
\hline Case & Age & Sex & $\begin{array}{l}\text { Pathological } \\
\text { diagnosis }\end{array}$ & Surgical procedure & $\begin{array}{l}\text { Severed lumbosacral } \\
\text { nerves }\end{array}$ & $\begin{array}{l}\text { Follow up } \\
\text { period } \\
\text { (months) }\end{array}$ \\
\hline 1 & 58 & $\mathrm{~F}$ & Chondrosarcoma & $\begin{array}{l}\text { Radical resection and right sacroiliac reconstruction } \\
\text { with ISOLA and bone cement }\end{array}$ & $\begin{array}{l}\text { Right L4-S5 } \\
\text { Left L5-S5 }\end{array}$ & 12 \\
\hline 2 & 66 & M & Meningioma & $\begin{array}{l}\text { Radical resection and reconstruction of the sacrum } \\
\text { with autologous bone }\end{array}$ & Bilateral L5-S5 & 42 \\
\hline 3 & 54 & $\mathrm{M}$ & Giant cell tumour & $\begin{array}{l}\text { Radical resection and reconstruction of the sacrum } \\
\text { with autologous bone }\end{array}$ & Bilateral S1-S5 & 15 \\
\hline 4 & 33 & $\mathrm{~F}$ & Ependymoma & $\begin{array}{l}\text { Radical resection and reconstruction of the sacrum } \\
\text { with Harrington instrumentation and autologous } \\
\text { bone }\end{array}$ & Bilateral S1-S5 & 98 \\
\hline 5 & 17 & M & Ewing's sarcoma & $\begin{array}{l}\text { Radical resection and reconstruction of the sacrum } \\
\text { with bone cement }\end{array}$ & Bilateral S2-S5 & 11 \\
\hline 6 & 72 & M & Chordoma & Radical resection & Bilateral S3-S5 & 68 \\
\hline 7 & 71 & M & Chordoma & Radical resection & Bilateral S3-S5 & 30 \\
\hline 8 & 74 & M & Chordoma & $\begin{array}{l}\text { Radical resection and reconstruction of the sacrum } \\
\text { with Spine system }{ }^{\circledR} \text { and hydroxyapatite }\end{array}$ & $\begin{array}{l}\text { Right S3-S5 } \\
\text { Left S4-S5 }\end{array}$ & 9 \\
\hline
\end{tabular}

$\mathrm{L}=$ lumbar, $\mathrm{S}=$ sacral. 
Table II Muscle strength, reflexes and sensation in patients after bilateral severance of lumbosacral nerves

\begin{tabular}{|c|c|c|c|c|c|c|c|c|c|c|c|c|}
\hline \multirow[t]{2}{*}{ Case } & \multirow{2}{*}{$\begin{array}{l}\text { Severed } \\
\text { lumbosacral } \\
\text { nerves }\end{array}$} & \multicolumn{7}{|c|}{ Muscle strength } & \multicolumn{3}{|c|}{ Reflex } & \multirow[t]{2}{*}{ Sensation } \\
\hline & & & IP & QR & TA & EHL & $\mathrm{GC}$ & FHL & PTR & ATR & AR & \\
\hline \multirow[t]{2}{*}{1} & Right L4-S5 & Right & 5 & 4 & 0 & 0 & 0 & 0 & - & - & - & $\begin{array}{l}\text { Sensory loss of Right } \\
\text { L4-S5 }\end{array}$ \\
\hline & Left L5-S5 & Left & 5 & 4 & 2 & 0 & 0 & 0 & \pm & - & - & $\begin{array}{l}\text { Sensory loss of Left } \\
\text { L5-S5 }\end{array}$ \\
\hline \multirow[t]{2}{*}{2} & Bilateral L5-S5 & Right & 5 & 5 & 4 & 3 & 3 & 0 & + & - & - & $\begin{array}{c}\text { Hypaesthesia of } \\
\text { bilateral L4 }\end{array}$ \\
\hline & & Left & 5 & 5 & 3 & 3 & 3 & 0 & + & - & - & $\begin{array}{l}\text { Sensory loss of } \\
\text { bilateral L5-S5 }\end{array}$ \\
\hline \multirow[t]{2}{*}{3} & Bilateral S1-S5 & Right & 5 & 5 & 5 & 4 & 4 & 3 & \pm & - & - & $\begin{array}{c}\text { Hypaesthesia of } \\
\text { bilateral S1 }\end{array}$ \\
\hline & & Left & 5 & 5 & 5 & 4 & 4 & 3 & \pm & - & - & $\begin{array}{l}\text { Sensory loss of } \\
\text { bilateral S2-S5 }\end{array}$ \\
\hline \multirow[t]{2}{*}{4} & Bilateral S1-S5 & Right & 5 & 5 & 5 & 4 & 4 & 3 & + & - & - & $\begin{array}{l}\text { Hypaesthesia of } \\
\text { bilateral L5 }\end{array}$ \\
\hline & & Left & 5 & 5 & 5 & 4 & 3 & 2 & \pm & - & - & $\begin{array}{l}\text { Sensory loss of } \\
\text { bilateral S1-S5 }\end{array}$ \\
\hline \multirow[t]{2}{*}{5} & Bilateral S2-S5 & Right & 5 & 5 & 5 & 5 & 4 & 4 & + & \pm & - & $\begin{array}{c}\text { Hypaesthesia of } \\
\text { bilateral S1 }\end{array}$ \\
\hline & & Left & 5 & 5 & 4 & 4 & 4 & 4 & + & \pm & - & $\begin{array}{l}\text { Sensory loss of } \\
\text { bilateral S2-S5 }\end{array}$ \\
\hline \multirow[t]{2}{*}{6} & Bilateral S3-S5 & Right & 5 & 5 & 5 & 5 & 5 & 5 & + & \pm & - & $\begin{array}{c}\text { Hypaesthesia of } \\
\text { bilateral S3 }\end{array}$ \\
\hline & & Left & 5 & 5 & 5 & 5 & 5 & 5 & \pm & \pm & - & $\begin{array}{l}\text { Sensory loss of } \\
\text { bilateral S4-S5 }\end{array}$ \\
\hline \multirow[t]{2}{*}{7} & Bilateral S3-S5 & Right & 5 & 5 & 5 & 5 & 5 & 5 & + & \pm & - & $\begin{array}{c}\text { Hypaesthesia of } \\
\text { bilateral S3 }\end{array}$ \\
\hline & & Left & 5 & 5 & 5 & 5 & 5 & 5 & + & \pm & - & $\begin{array}{l}\text { Sensory loss of } \\
\text { bilateral S4-S5 }\end{array}$ \\
\hline \multirow[t]{2}{*}{8} & Right S3-S5 & Right & 5 & 5 & 5 & 5 & 5 & 5 & + & + & - & $\begin{array}{l}\text { Hypaesthesia of } \\
\text { bilateral S4-S5 }\end{array}$ \\
\hline & Left S4-S5 & Left & 5 & 5 & 5 & 5 & 5 & 5 & + & + & + & \\
\hline
\end{tabular}

Number of muscle strength $=$ grade of MMT $(5=$ normal, $4=$ good, $3=$ fair, $2=$ poor, $1=$ trace, $0=$ zero $)$, IP $=$ iliopsoas, QR $=$ quadriceps, $\mathrm{TA}=$ tibialis anterior, $\mathrm{EHL}=$ extensor hallucis longus, $\mathrm{GC}=$ gastrocnemius, $\mathrm{FHL}=$ flexor hallucis longus, $\mathrm{AR}=$ anal reflex. 
Table III Urinary, faecal and sexual functions in patients after bilateral severance of lumbosacral nerves

\begin{tabular}{|c|c|c|c|c|c|c|c|c|c|c|c|}
\hline \multirow[t]{2}{*}{ Case } & \multirow{2}{*}{$\begin{array}{l}\text { Severed } \\
\text { lumbosacral } \\
\text { nerves }\end{array}$} & \multicolumn{3}{|c|}{ Urinary function } & \multicolumn{4}{|c|}{ Faecal function } & \multicolumn{3}{|c|}{ Sexual function } \\
\hline & & $\begin{array}{c}\text { Normal } \\
\text { uriesthesia }\end{array}$ & $\begin{array}{l}\text { Residual } \\
\text { urine }\end{array}$ & $\begin{array}{l}\text { Inconti- } \\
\text { nence }\end{array}$ & $\begin{array}{c}\text { Normal } \\
\text { defaecation } \\
\text { sensation }\end{array}$ & $\begin{array}{l}\text { Consti- } \\
\text { pation }\end{array}$ & $\begin{array}{l}\text { Inconti- } \\
\text { nence }\end{array}$ & $\begin{array}{l}\text { Sphincter } \\
\text { tonus }\end{array}$ & Erection & $\begin{array}{l}\text { Ejacula- } \\
\text { tion }\end{array}$ & $\begin{array}{c}\text { Sensibility } \\
\text { of penis }\end{array}$ \\
\hline 1 & $\begin{array}{l}\text { Right L4-S5 } \\
\text { Left L5-S5 }\end{array}$ & - & + & + & - & + & + & - & & & \\
\hline 2 & BilateralL5-S5 & - & + & + & - & + & + & - & - & - & - \\
\hline 3 & Bilateral S1-S5 & - & + & + & - & + & + & - & - & - & - \\
\hline 4 & Bilateral S1-S5 & - & + & + & - & + & + & - & & & \\
\hline 5 & Bilateral S2-S5 & - & + & + & - & + & + & - & \pm & - & - \\
\hline 6 & Bilateral S3-S5 & - & + & \pm & - & + & \pm & \pm & \pm & \pm & + \\
\hline 7 & Bilateral S3-S5 & - & + & \pm & - & + & \pm & \pm & \pm & \pm & + \\
\hline 8 & $\begin{array}{l}\text { Right S3-S5 } \\
\text { Left S4-S5 }\end{array}$ & + & \pm & - & + & - & - & + & + & + & + \\
\hline
\end{tabular}

$+=$ present,$\pm=$ weak or decreased, $-=$ absent. 
biomechanical study of pelvic strength and neurological dysfunction after radical sacral tumor resection. ${ }^{7,13-16}$ However, the relationship between the level of sacral amputation and neurological deficits is not well described because it would appear that few patients have been studied and reported. We have investigated the neurological deficits relative to the level of bilateral several of the lumbosacral nerves and clarified the relationship with ADL.

The neurological deficits relative to the level of spinal nerve severance and their relationship with disturbances of ADL such as walking, urinary function, faecal function and sexual function were as follows. After bilateral severance of the L5 nerve and below, walking was possible with support, but intermittent self catheterisation and diapers became necessary, and sexual function was lost. After bilateral severance of the S1 nerve and below, walking independently was possible. After bilateral severance of the S2 nerve and below, a weak erection occurred but ejaculation was not possible. After bilateral severance of the S3 nerve and below, walking was normal and, although intermittent self catheterisation occasionally became necessary, urinary incontinence was minimal. Faecal incontinence did not occur with solid faeces but did occur with soft faeces. Regarding sexual function, a slightly reduced erection was established and dripping of semen occurred instead of normal ejaculation. After unilateral preser- vation of the S3 nerve, urinary, faecal and sexual dysfunction were almost nonexistent. Our results indicate that the L5 nerve and above must be preserved bilaterally to allow walking and the $\mathrm{S} 2$ nerve and above must be preserved to permit urinary, faecal and sexual function. These are the minimal requirements to maintain ADL. But bilateral preservation of the S2 nerve and above is necessary for walking and bilateral preservation of the S3 nerve and above is necessary to maintain urinary, faecal and sexual functions.

It is understood that sparing of as many lumbosacral nerves as possible in radical sacral tumour resection is essential to preserve as much neurological function as possible. It is also important to give a thorough explanation to the patient preoperatively so that he/she appreciates the possible neurological effects of radical sacral neoplasm surgery.

\section{Conclusion}

Neurological deficits relative to the level of bilateral spinal severance of lumbosacral nerves necessary for the surgical excision of sacral neoplasms were studied in eight patients. We conclude that it is necessary to bilaterally preserve the L5 nerves and above with regard to walking, and bilaterally preserve the S2 nerves and above with regard to urinary, faecal and sexual function in order to establish ADL.

\section{References}

1 Bower RF (1948) Giant cell tumor of the sacrum: a case report. Ann Surg 128: 1164-1172.

2 MacCarty CS, Waugh JM, Mayo CW, Coventry MB (1952) The surgical treatment of presacral tumors: a combined problem. Proc Staff Meet Mayo Clin 27: 73-84.

3 Hays RP (1953) Resection of the sacrum for benign giant cell tumor: a case report. Ann Surg 138: $115-120$

4 MacCarty CS, Waugh JM, Coventry MB, Cope WF Jr (1965) Surgical treatment of sacral and presacral tumors other than sacrococcygeal chordoma. J Neurosurg 22: 458-464.

5 Localio SA, Francis KC, Rossano PG (1967) Abdomino-sacral resection of sacrococcygeal chordoma. Ann Surg 166: 394-402.

6 Freier DT, Stanley JC, Thompson NW (1971) Retrorectal tumors in adults. Surg Gynec Obstet 132: 681-686.

7 Gunterberg B (1976) Effects of major resection of the sacrum: clinical studies on urogenital and anorectal function and a biomechanical study on pelvic strength. Acta Orthop Scand Suppl 162: 1-38.

8 Localio SA, Eng K, Ranson JHC (1980) Abdominosacral approach for retrorectal tumors. Ann Surg 191: 555-560.

9 Rengachary SS, O’Boynick P, Batnitzky S, Kepes JJ (1981) Giant intrasacral schwannoma: case report. Neurosurgery 9: 573-577. 
10 Abernathey CD, Onofrio BM, Scheithauer B, Pairolro PC, Shives TC (1986) Surgical management of giant sacral schwannomas. J Neurosurg 65: 286-295.

11 Gennari L, Azzarelli A, Quagliuolo V (1987) A posterior approach for the excision of sacral chordoma. $J$ Bone Joint Surg 69B: 565-568.

12 Shikata J, Yamamuro T, Kotoura Y, Mikawa Y, Iida H, Maetani S (1988) Totàl sacrectomy and reconstruction for primary tumors. J Bone Joint Surg 70A: 122-125.

13 Gunterberg B, Norlén L, Stener B, Sundin T (1975) Neurorologic evaluation after resection of the sacrum. Invest Urol 13: 183-188.

14 Gunterberg B, Kewenter J, Petersén I, Stener B (1976) Anorectal function after major resections of the sacrum with bilateral or unilateral sacrifice of sacral nerves. Br J Surg 63: 546-554.

15 Gunterberg B, Petersén I (1976) Sexual function after major resections of the sacrum with bilateral or unilateral sacrifice of sacral nerves. Fertil Steril 27: 1146-1153.

16 Stener B, Gunterberg B (1978) High amputation of the sacrum for extirpation of tumors: principles and technique. Spine 3: 351-366.

17 Hudson TM, Galceran M (1983) Radiology of sacrococcygeal chordoma: difficulties in detecting soft tissue extension. Clin Orthop 175: 237-242.

18 Krol G, Sundaresan N, Deck M (1983) Computed tomography of axial chordomas. J Comput Assist Tomogr 7: 286-289.

19 Pettersson H, Hudson T, Hamlin D et al (1985) Magnetic resonance imaging of sacrococcygeal tumors. Acta Radiol Diagn 26: 161-165.

20 Harrington PR (1962) Treatment of scoliosis: correction and internal fixation by spine instrumentation. $J$ Bone Joint Surg 44A: 591-610.

21 Luque ER (1982) The anatomic basis and development of segmental spinal instrumentation. Spine 7: 256-259.

22 Steffee AD, Biscup RS, Sitkowski DJ (1986) Segmental spine plates with pedicle screw fixation: a new internal fixation device for disorders of the lumbar and thoracolumbar spine. Clin Orthop 203: 45-53. 